IZA DP No. 5284

Bonus Payments, Hierarchy Levels and Tenure: Theoretical Considerations and Empirical Evidence

Christian Grund

Matthias Kräkel

October 2010 


\title{
Bonus Payments, Hierarchy Levels and Tenure: Theoretical Considerations and Empirical Evidence
}

\author{
Christian Grund \\ University of Würzburg \\ and IZA \\ Matthias Kräkel \\ University of Bonn \\ and IZA

\section{Discussion Paper No. 5284 \\ October 2010} \\ IZA \\ P.O. Box 7240 \\ 53072 Bonn \\ Germany \\ Phone: $+49-228-3894-0$ \\ Fax: +49-228-3894-180 \\ E-mail: iza@iza.org
}

Any opinions expressed here are those of the author(s) and not those of IZA. Research published in this series may include views on policy, but the institute itself takes no institutional policy positions.

The Institute for the Study of Labor (IZA) in Bonn is a local and virtual international research center and a place of communication between science, politics and business. IZA is an independent nonprofit organization supported by Deutsche Post Foundation. The center is associated with the University of Bonn and offers a stimulating research environment through its international network, workshops and conferences, data service, project support, research visits and doctoral program. IZA engages in (i) original and internationally competitive research in all fields of labor economics, (ii) development of policy concepts, and (iii) dissemination of research results and concepts to the interested public.

IZA Discussion Papers often represent preliminary work and are circulated to encourage discussion. Citation of such a paper should account for its provisional character. A revised version may be available directly from the author. 
IZA Discussion Paper No. 5284

October 2010

\section{ABSTRACT}

\section{Bonus Payments, Hierarchy Levels and Tenure: Theoretical Considerations and Empirical Evidence*}

Using data on executive compensation for the German chemical industry, we investigate the relevance of two theoretical approaches that focus on bonuses as part of a long term wage policy of a firm. The first approach argues that explicit bonuses serve as substitutes for implicit career concerns. The second approach claims that bonuses are used as complements to an executive's internal career. Our data show that bonus payments are mostly prevalent among senior executives at higher hierarchy levels and rather for management jobs than for jobs in research and development. This is true for the whole chemical sector as well as for single large corporations. The findings indicate that the two theoretical views are not mutually exclusive, but are both relevant in practice.

JEL Classification: M52, J33

Keywords: bonus payments, chemical sector, hierarchy, tenure, wage policy

Corresponding author:

Christian Grund

Department of Business and Economics

University of Würzburg

Sanderring 2

97070 Würzburg

Germany

E-mail: ch.grund@uni-wuerzburg.de

\footnotetext{
* Many thanks to Martin Kukuk and two anonymous referees for helpful comments and to Johannes Martin for preparing the data set. Financial support by the Deutsche Forschungsgemeinschaft (DFG), grant SFB/TR 15 ("Governance and the Efficiency of Economic Systems") is gratefully acknowledged.
} 


\section{Bonus Payments, Hierarchy Levels and Tenure: Theoretical Considerations and Empirical Evidence}

\section{Introduction}

Executives are rewarded according to both long-term and short-term performance. Following the traditional view on executive compensation, promotion-based incentive schemes are used to honor long-term success, whereas bonus-based incentive schemes typically fix annual payments to focus on short-term goals (Baker, Jensen and Murphy 1988). In the last two decades, applied contract theory has emphasized that bonus payments can also be seen as part of a long-term wage policy of a firm. In particular, two approaches have contributed to this view. First, Gibbons and Murphy (1992) pointed out that the optimal incentive mix consists of explicit pay-for-performance (i.e., bonuses) and implicit career incentives. ${ }^{1}$ In the beginning of an employee's career, high ability uncertainty provides strong career concerns so that the firm can skip high powered explicit incentives. However, the more ability uncertainty diminishes the less effective will be career concerns for employee motivation and the firm must more strongly rely on bonus payments as explicit incentives. Hence, according to Gibbons and Murphy (1992), bonuses and career incentives are substitutes, implying a positive relation between tenure and bonus payments of employees.

Second, bonus payments and an executive’s internal career may also be complements: In the case of limited liability, linking job promotion to individual performance generates strong incentives for executives at lower levels since climbing the ladder is associated with significant rents when attaining higher levels of the hierarchy. As rents at higher tiers of a corporate hierarchy can only be used for incentive purposes when being combined with job promotion, bonuses and internal careers are complements within the optimal wage policy of a firm (Kräkel and Schöttner 2009, 2010). According to this view, bonus payments are positively related to hierarchy levels in the sense that bonuses increase upwards a corporate hierarchy.

In this paper, by using data from the German chemical industry we explore whether real executive compensation is in line with these two approaches. The two approaches are not mutually exclusive as bonuses at high hierarchy levels may serve both purposes - being a

\footnotetext{
${ }^{1}$ See Fama (1980) and Holmström $(1982,1999)$ on implicit incentives via career concerns.
} 
substitute for missing implicit career incentives and transferring rents to executives. Hence, there are four possible outcomes: (1) only the substitutes approach turns out to be valid, (2) only the complements approach is valid, (3) both approaches are supported by the data, or (4) neither approach proves relevant in practice. The data provide detailed information of more than 5,000 executives. In particular, we know all components of each executive's compensation, his or her ${ }^{2}$ hierarchy level, tenure, occupational skills and other individual characteristics. We use two proxies for the intensity of bonus pay: first, the fact whether an executive has a bonus contract or not, and second, the executive's individual bonus income relative to his total compensation. Whereas the first indicates the contractual pay for performance relevance, the second measures the actual pay for (individual, group and/or firm) performance. The results indicate that bonus contracts and payments are mostly prevalent among executives with large tenure at higher tiers of the corporate hierarchy and rather for management jobs than for jobs in research and development. Hence, the data offer empirical support for both the substitutes approach and the complements approach.

Concerning the complements approach, note that the use of bonuses is only one of several alternatives to transfer rents to executives. For example, promotion can be directly accompanied by an increase of the executive's base wage. Moreover, there are non-monetary rewards like flexible working time and discretion (e.g., Lazear 1995, pp. 57-62, 85, 1998, chapter 14) as well as perks like company cars and nice offices (e.g., Marino and Zábojnik 2008a, b), which are particularly important for managers. Since we only focus on bonuses in our paper, this may lead to an underestimation of rent transfer. Therefore, including additional sources of rent transfer would even strengthen our empirical findings.

To the best of our knowledge the substitutes approach has not been empirically compared with the complements approach so far. Nevertheless, our paper is related to part of the compensation literature. There is a rich literature on executive pay with a special focus on the compensation of chief executive officers (CEOs) (e.g., Murphy 1999 for an overview). Hereby, many contributions focus on stock options and not on bonus payments. As an exception, Gibbons and Murphy (1992) empirically tested their substitutes approach by using publicly available data on salaries, bonuses and other compensation ingredients of 3,000 CEOs from the U.S. The results are in line with their theoretical model of explicit and implicit

\footnotetext{
${ }^{2}$ We use the male form for managers and the female form for the employer in the remainder of this contribution for simplicity.
} 
incentives being substitutes by showing that pay for performance sensibilities are higher for CEOs nearing retirement.

The career-concerns part of the substitutes approach has also been experimentally tested in the laboratory. For their experiments, Irlenbusch and Sliwka (2006) as well as Koch, Morgenstern and Raab (2009) used a simplified two-period version of the well-known career-concerns model by Holmström (1982, 1999). The two experimental papers yield mixed results on the validity of career concerns for real decision makers.

Another strand of the literature explores the wage policy of single firms. For instance, Baker, Gibbs and Holmström (1994a, 1994b) as well as Treble et al. (2001) use personnel records and examine the white collar workforces of single financial sector firms. They concentrate on fix wages and abstain from dealing with bonuses, though. In a recent case study, Ockenfels, Sliwka and Werner (2010) examine a large firm with subsidiaries in Germany and the U.S. and focus on perceived reference points of bonus payments. The authors explore consequences (e.g., job satisfaction, supervisor performance) of bonuses rather than determinants.

Ortin-Angel and Salas-Fumas (1998) examine determinants of bonus incidence and bonus levels based on individual cross section data from Spain in 1990. They refer to Gibbs (1995) who - similar to the model of Gibbons and Murphy (1992) - predicts that explicit bonus payments and implicit career incentives are substitutes in the optimal compensation package for managers. Ortin-Angel and Salas-Fumas point out that their results support the substitutes model of Gibbs (1995). Their empirical study differs from ours in several respects. First, they do not explore the bonus fraction relative to total compensation. Second, they do not analyze the bonus policy of single firms. As the two authors consider different sectors of the Spanish economy, they investigate sectoral patterns of managerial compensation, whereas our study concentrates on one industry with more homogeneous firms. Third, they do not investigate the complements approach.

Note that there also exist other compensation theories that lead to similar predictions as the substitutes and the complements approaches - a positive relationship between hierarchy level and tenure on the one hand and managerial compensation on the other hand. However, these theories deal with the increase of base salaries and not with pay for performance in form of bonuses. Therefore, our bonus data cannot be used to investigate the relevance of these theories. Two of the most prominent approaches dealing with base salary and hierarchy level 
or tenure, respectively, are introduced by Rosen (1982, 1986). In Rosen (1982), the effort of a certain manager influences the values of marginal product of all subordinate managers. Consequently, the higher a manager is located in the corporate hierarchy the higher should be his base salary. Rosen (1986) considers a dynamic tournament model. In order to motivate risk-averse employees in a corporate hierarchy, wage differentials between hierarchy levels should be positive and increasing along the promotion ladder. In particular, the spread between CEO compensation and the base salary of the vice president of the corporation should be very large to induce incentives for all employees that have a positive probability to become CEO once in their career.

The remainder of the paper is organized as follows: Section 2 describes the substitutes approach and the complements approach in more details, and suggests three hypotheses. The data are introduced in Section 3. The main empirical findings are derived in Section 4. Section 5 concludes.

\section{Intertemporal Incentives and Bonus Payments - Theoretical Considerations and Hypotheses}

Bonuses are typically used for creating short-term incentives. If, for example, the performance of a certain department exceeds a given annual threshold, the respective department manager will receive a prespecified bonus for this year. However, bonus payments can also play an important role in the long run. In the following subsections, we present two alternatives for creating incentives that work against moral hazard of employees. We argue that bonuses can either substitute or complement implicit career incentives. In the substitute case, bonus payments and tenure should be positively related. In the complement case, there should be a positive relation between bonus payments and hierarchy level (i.e., bonus contracts should be particularly observed on high levels of a corporate hierarchy).

\section{Bonuses as Career Substitutes}

The first approach has been analyzed by Gibbons and Murphy (1992). It is based on the seminal papers by Fama (1980) and Holmström (1982, 1999), addressing the topic of career concerns: Fama and Holmström assume that labor market competition for talented employees leads to a strictly positive relation between an employee's expected talent and his market 
value. The higher the expected talent is, the higher will be the reservation value of the employee and, therefore, the higher the actual payment by his current employer. When an employee starts working and enters a low level of a corporate hierarchy there is still high uncertainty about his true productivity or talent. This uncertainty is symmetric between employee and employer so that both learn from the employee's success and failure on the job. Technically, the employee's productivity can be described by a random variable that follows a given prior distribution, based on previous experiences and statistical information. Due to Bayesian updating, every success of the employee shifts probability mass from the left of the distribution to the right, thus increasing the employee's posterior expected productivity and thereby his market value. Conversely, every failure leads to a probability shift from the right to the left and, therefore, decreases the employee's posterior expected productivity. In this early stage of an employee's career with high talent uncertainly, individuals have very strong career incentives since success and failure have a high impact on the posterior talent distribution, determining the individuals' reservation values. Consequently, they choose high effort levels. The more talent uncertainty diminishes as tenure increases, the smaller will be an employee's career incentives. From a technical perspective, low talent uncertainty means that the variance of the employee's unknown productivity shrinks or, in other words, the precision of observed performance as a signal of underlying productivity increases. Now, additional observations on success and failure only have less influence on the redistribution of posterior probability mass. As a consequence, if tenure rises the employee will reduce effort in order to save effort costs.

Gibbons and Murphy (1992) combine the career-concerns model with bonuses to analyze a firm's optimal mix of explicit and implicit incentives. They assume that an employee's output to the firm in period $t, y_{t}$, is linear in effort chosen by the employee in that period, $e_{t}$, and the employee's unknown talent, $\eta$ :

$$
y_{t}=\eta+e_{t}+\varepsilon_{t} .
$$

Unknown talent $\eta$ is modeled as a random variable that follows a certain distribution with variance $\operatorname{Var}[\eta]$. According to the assumption of symmetric talent uncertainty, this distribution is common knowledge for the employer, the employee and the remaining labor market. $\varepsilon_{t}$ is a random noise variable for period $t$ (e.g., denoting measurement error) with noise being stochastically independent across periods. Output is observable and verifiable by the firm, whereas talent, effort and noise are unobservable. Hence, we have a moral hazard 
problem. The firm is assumed to be risk neutral, but the employee is risk averse. Gibbons and Murphy assume that long-term or multi-period contracts are not feasible.

At the beginning of an employee's career, $\operatorname{Var}[\eta]$ is rather large. On the one hand, following the career-concerns approach, this high talent uncertainty leads to strong implicit career incentives. On the other hand, explicit incentives via a bonus contract based on observed output are very costly for the firm: Since $\operatorname{Var}[\eta]$ is large, output is mainly determined by the exogenous random variable $\eta$. In order to motivate the employee in such situations, the firm must offer very high bonuses in case of high outputs. Moreover, since the employee is risk averse a large value of $\operatorname{Var}[\eta]$ will be associated with a large risk premium, if the employee is incentivized via bonuses. This risk premium is completely paid by the firm given that the employee is not protected by limited liability. For these reasons, the firm will use implicit career incentives but does not offer explicit bonus payments if the employee is at the beginning of his career. As employee tenure increases, talent uncertainty diminishes. The more the uncertainly is reduced (i.e., the smaller $\operatorname{Var}[\eta]$ ), the less effective will be implicit career incentives, which has been pointed out above. In this situation, the firm will use bonus schemes as a substitute for missing career incentives. If an employee's tenure is quite high, there is only marginal talent uncertainty so that implicit career incentives are completely replaced by explicit bonus schemes. Low talent uncertainty makes these bonuses very effective and rather cheap for the firm. Altogether, the optimal incentive mix leads to a strong positive relationship between tenure and bonuses, yielding our first hypothesis:

Hypothesis 1: The relevance of bonus payments increases in tenure.

This substitutes approach is based on career concerns due to talent uncertainty. If this approach is highly relevant, then career incentives (instead of bonuses) should be prevalent for jobs, in which talent uncertainty matters, whereas bonus contracts should be attached to those jobs with routine and administrative dominated tasks. Thus, we should observe less relevance of bonus payments at research and development jobs. Here, high talent uncertainty should favor implicit career incentives instead of explicit pay for performance in form of bonuses. Note that career incentives for industrial researchers can take two different forms. On the one hand, researchers may be interested to climb up the hierarchy by becoming head of the research department or by switching to the management track. On the other hand, researchers may primarily be interested to stay in the research area. For these individuals, 
career incentives can be generated by promising higher research budgets or promotion along a special research track, the so-called dual ladder (see already Smith and Szabo (1977) on the dual ladder at Union Carbide in the 1970s). Talent uncertainty plays a minor role for managerial tasks at rather administrative jobs in the areas of controlling, finance, marketing and HR. For these jobs, explicit incentives via bonus payments should be more important.

Hypothesis 2: Bonuses should mainly be paid at management jobs rather than in research and development.

\section{Bonuses as Complements to Internal Careers}

If, contrary to the career-concerns approach, initial talent uncertainty of young employees' is not an issue (e.g., due to formal qualifications that credibly signal true talent in the sense of Spence 1973), career incentives may still work when being complemented by bonus payments at higher hierarchy levels: Let an employee's output in period $t$ again be described by the linear production function $y_{t}=\eta+e_{t}+\varepsilon_{t}$. However, without talent uncertainty the variable $\eta$ is now deterministic and common knowledge. Because of unobservable noise $\varepsilon_{t}$ the employer still faces a moral hazard problem. She can use a bonus contract $\left(b_{L}, b_{H}\right)$ to induce incentives to her employees. The high bonus $b_{H}$ will be paid to an employee if realized output exceeds a certain standard $y$ (i.e., $y_{t}>y$ ), whereas the low bonus $b_{L}\left(<b_{H}\right)$ is given to the employee otherwise (i.e., $y_{t}<y$ ). Suppose that employees are protected by limited liability (see, e.g., Sappington 1983; Innes 1990; Kim 1997) in the sense that bonuses are not allowed to be negative. Moreover, let the employees be risk neutral and be characterized by a convex disutility-of-effort function (in monetary terms) $c\left(e_{t}\right)$ with $c(0)=c^{\prime}(0)=0$. Finally, let the employees’ reservation values be normalized to zero.

We can exemplarily sketch the optimal contract for the employees at the highest hierarchy level. In the given setting, an employee maximizes his expected utility

$$
\begin{aligned}
& \operatorname{prob}\left\{y_{t}>y\right\} b_{H}+\operatorname{prob}\left\{y_{t}<y\right\} b_{L}-c\left(e_{t}\right) \\
= & {\left[1-\operatorname{prob}\left\{\varepsilon_{t}<y-\eta-e_{t}\right\}\right] b_{H}+\operatorname{prob}\left\{\varepsilon_{t}<y-\eta-e_{t}\right\} b_{L}-c\left(e_{t}\right) } \\
= & b_{L}+\left(b_{H}-b_{L}\right)\left[1-F\left(y-\eta-e_{t}\right)\right]-c\left(e_{t}\right)
\end{aligned}
$$


with $F$ as the cumulative distribution function of the random variable $\varepsilon_{t}$. If the employee's objective function is strictly concave, optimal effort choice is described by the first-order condition

$$
\left(b_{H}-b_{L}\right) F^{\prime}\left(y-\eta-e_{t}\right)=c^{\prime}\left(e_{t}\right) \text {. }
$$

Hence, for a given standard and given bonuses an employee's optimal effort equates marginal expected bonus payments and marginal costs.

Now we consider the employer's bonus contract. First, note that the employee's participation constraint can be neglected by the employer when solving for the optimal contract, that is, the employee will earn a non-negative rent in the optimum: Since bonuses are non-negative due to limited liability and $c(0)=0$, by accepting any feasible contract and choosing zero effort an employee can ensure himself an expected utility that is at least as large as his zero reservation value. Second, the optimal low bonus $b_{L}$ is zero since incentives decrease and expected labor costs increase in $b_{L}$. The optimal high bonus $b_{H}$ maximizes the employer's expected net profits $E\left[y_{t}\right]-b_{H}\left[1-F\left(y-\eta-e_{t}\right)\right]$ subject to the incentive constraint $\left.b_{H} F^{\prime}\left(y-\eta-e_{t}\right)\right]=$ $c^{\prime}\left(e_{t}\right)$ and the limited-liability constraint, which is strictly positive in the optimum (i.e., $b_{H}>$ $0)$. In any case, an employee at the highest hierarchy level will earn a strictly positive rent if the employer wants to implement positive effort levels.

When looking at lower hierarchy levels, we have a completely different situation. Employees located at lower levels anticipate that they will earn expected bonus payments and, hence, positive rents if being promoted to higher levels. This expectation generates strong career incentives even if employees’ talents are perfectly known in the beginning. Since expected bonuses at the top of the hierarchy complement an employee's internal career along a certain ladder and already imply high efforts on lower hierarchy levels, the firm may optimally forego bonus schemes at these levels (see Kräkel and Schöttner 2009, 2010).

Both models may lead to the same observation that high-tenured employees have successfully climbed the ladder and now earn large bonus payments at high hierarchy levels, whereas lowtenured employees at lower ranks of the hierarchy are only offered few if any bonus contracts. However, the substitutes issue focuses on tenure, whereas certain hierarchy levels of a firm are necessary for the complements argument. In practice, both arguments may well be relevant. Empirically it is possible to disentangle tenure from hierarchy level effects. Aiming to check the relevance of the complements argument, we formulate 
Hypothesis 3: Bonus payments are more relevant at higher levels of the hierarchy.

\section{Data and Variables}

Examining the hypotheses, we make use of a new and unique data set of highly qualified professionals and executive staff of the German chemical industry. The chemical industry is important for the whole German economy and dominated by large firms. Subsectors include fine and special chemicals, polmers, pharmaceutical products, petrochemicals, detergents and toiltries as well as anorganic chemicals. The association of the chemical industry (Verband der Chemischen Industrie - VCI) reports an aggregate revenue of the ten largest firms of the sector of over 180 billion $€$ in 2008. These ten firms have employed almost 600,000 employees worldwide (see Table $\mathrm{A}$ in the appendix for detailed numbers of single firms). Over 400.000 employees are employed in the German chemical sector. Most of them are not employed as executives and covered by collective wage agreements, though.

In collaboration with the German association of executive staff of the chemical industry (Verband angestellter Akademiker und leitender Angestellter der Chemischen Industrie e.V. (VAA)) we conduct a salary survey. In March 2009, the survey has been sent to VAA members and also to members of a partner association GDCh (Gesellschaft deutscher Chemiker e.V.), from which about 33 percent respond. According to VAA and GDCh, our sample is representative for the respective employees of the chemical sector. Individuals are asked about their current job next to some demographics and their previous occupational career. In particular, we have detailed information on all components of their 2008 salary such as fix wages, bonuses and other integral parts such as exercised stock options, inventors' gratuities or jubilee payments. We have valid information for 5,586 employees.

In this contribution, we concentrate on bonuses. First, we examine, whether employees have some kind of bonus contract. Over 90 percent of employees in the sample affirm a corresponding question and over 90 percent of this group actually reports a positive bonus for the year 2008. Second, the fraction of the bonus on total yearly salary is taken into account. The average bonus fraction amounts to 0.16 . These two variables act as dependent variables in our empirical analysis. Table 1 provides an overview of descriptive statistics for these and other variables. The average bonus of those who receive such payments is about $€ 21,000$. 
In correspondence to our hypotheses stated in section 2 above, the most important independent variables are tenure, hierarchy level and functional area. Tenure is measured in years. Focusing on special effects on new hires, we also compare three categories of tenure ((i) less than 5 years, (ii) 5 to 19 years, (iii) at least 20 years). Functional areas are divided into nine categories. About 30 percent of the employees work in the field of R\&D. One of six employees is allocated to a typical management task such as marketing, finance, controlling or HR. Respondents are also asked to allocate themselves to one of four management levels from 1 to 4 . Hereby, level 1 represents the top-management level. ${ }^{3}$ Jobs at a certain level are likely to differ between firms with respect to firm size. Therefore, it makes sense to control for firm size as well. We can distinguish between eight categories with regard to the number of firms' employees. As mentioned above, the chemical sector is dominated by large firms. More than three quarter of respondents work in firms with more than 1,000 employees.

We also control for sex, age, schooling degrees and field of study. We distinguish between apprenticeships, university of applied sciences and university graduates with regard to schooling, and between chemistry, other natural sciences, technical and business/economics degrees with regard to field of study. ${ }^{4}$ Additionally, we have information for the corporation in which the employees are employed for more than half of observations. We will use this information by examining whether our overall results are robust for single large corporations.

To the best of our knowledge, the data are unique with regard to the combination of sample size and the degree of information on salary components. Representative surveys of the whole population such as the IAB employment sample or the German Socio Economic Panel do not cover detailed information on bonus payments. Besides, it seems to be useful to have a more homogeneous sample of employees for the addressed research question.

\footnotetext{
${ }^{3}$ Although our data provide pretty good information about jobs of employees by knowing the level of the hierarchy and functional areas, we have to state that tasks and responsibility of jobs may even differ within groups. A level 1 manager may also have some further career opportunities by being promoted to the CEO.

${ }^{4}$ We exclude the very few observations with other degrees such as law and humanities from the analysis. This restriction does not have any effect on our results.
} 


\section{Results}

As a first illustration Figures 1 to 3 indicate the relevance of bonus payments for certain categories of tenure, hierarchy level and functional area. Although bonus contracts are also relevant for recently hired employees, the incidence increases with tenure from 0.83 for employees with less than 5 years to 0.95 for 20 and more years of tenure. Accordingly, the longtime employees face higher fractions of bonuses than the recently hired (0.18 vs 0.13$)$. At first glance, differences in hierarchy levels can be seen for the bonus fraction. There is no clear interrelation for the incidence of bonus contracts, though. Note, however, that other forms of performance related pay such as stock options are relevant particularly for managers at levels 1 and 2 .

Level 1 managers with a positive bonus indeed report particularly high payments of $€$ 55,000 on average. With regard to the functional area the bar graphs hint for particular bonus relevance in the typical management areas such as marketing, finance, controlling and HR. In contrast, the corresponding values for employees in the R\&D area are somewhat lower. Therefore, firms seem to distinguish bonus payments with regard to tenure, hierarchy level and functional area, although some institutional pressure may work against it. Usually, employees' interest groups such as works councils or the representative committee of executive employees try to avoid a substantially unequal treatment of employees. In a next step, we examine the impact of tenure, hierarchy level and functional area in more details. The figures also show $10^{\text {th }}, 25^{\text {th }}, 75^{\text {th }}$ and $90^{\text {th }}$ percentiles of bonus fraction. Intra-group differences are quite large. 
Table 1: Descriptive statistics

\begin{tabular}{|c|c|c|c|}
\hline Variable & $\mathbf{n}$ & Mean & $\begin{array}{l}\text { Standard } \\
\text { deviation }\end{array}$ \\
\hline $\begin{array}{l}\text { Bonus variables } \\
\text { Bonus contract [1=yes] } \\
\text { Bonus [€] } \\
\text { Bonus fraction [on total salary] }\end{array}$ & $\begin{array}{l}5,586 \\
4,807 \\
4,807\end{array}$ & $\begin{array}{c}0.917 \\
21,203 \\
0.160\end{array}$ & $\begin{array}{c}23,320 \\
0.080\end{array}$ \\
\hline $\begin{array}{l}\text { Tenure [years] } \\
0 \text { to } 4 \text { years of tenure } \\
5 \text { to } 19 \text { years of tenure } \\
20 \text { and more years of tenure }\end{array}$ & $\begin{array}{l}5,586 \\
879 \\
2,646 \\
2,061\end{array}$ & $\begin{array}{l}15.04 \\
0.157 \\
0.474 \\
0.369\end{array}$ & 8.908 \\
\hline $\begin{array}{l}1 \text { Level } \\
1 \text { (top management level) } \\
2 \\
3 \\
4\end{array}$ & $\begin{array}{c}128 \\
869 \\
2,569 \\
2,020\end{array}$ & $\begin{array}{l}0.023 \\
0.156 \\
0.460 \\
0.362\end{array}$ & \\
\hline $\begin{array}{l}\text { Production } \underline{J o b} \\
\text { Research and development } \\
\text { Technology } \\
\text { Applications engineering } \\
\text { Sales, marketing, logistics, sourcing } \\
\text { Finance, controlling, human resources } \\
\text { Technical supervision } \\
\text { IT } \\
\text { Other }\end{array}$ & $\begin{array}{c}1,029 \\
1,769 \\
572 \\
340 \\
629 \\
267 \\
311 \\
122 \\
547\end{array}$ & $\begin{array}{l}0.184 \\
0.317 \\
0.102 \\
0.061 \\
0.113 \\
0.048 \\
0.056 \\
0.022 \\
0.098\end{array}$ & \\
\hline $\begin{array}{l}\text { Less than } 100 \text { employees } \\
101 \text { to } 300 \text { employees } \\
301 \text { to } 1,000 \text { employees } \\
1,001 \text { to } 2,000 \text { employees } \\
2,001 \text { to 5,000 employees } \\
\text { 5,001 to } 10,000 \text { employees } \\
10,001 \text { to } 30,000 \text { employees } \\
\text { More than 30,000 employees }\end{array}$ & $\begin{array}{c}296 \\
321 \\
672 \\
602 \\
728 \\
650 \\
1,235 \\
1,082\end{array}$ & $\begin{array}{l}0.053 \\
0.058 \\
0.120 \\
0.108 \\
0.130 \\
0.116 \\
0.221 \\
0.194\end{array}$ & \\
\hline $\begin{array}{l}\text { University degree } \\
\text { University of applied sciences degree } \\
\text { Apprenticeship degree }\end{array}$ & $\begin{array}{c}4,894 \\
538 \\
154 \\
\end{array}$ & $\begin{array}{l}0.876 \\
0.096 \\
0.028 \\
\end{array}$ & \\
\hline $\begin{array}{l}\text { Chemistry Field of study } \\
\text { Other natural sciences / medicine } \\
\text { Engineering } \\
\text { Business/economics }\end{array}$ & $\begin{array}{c}3,058 \\
874 \\
1,411 \\
243\end{array}$ & $\begin{array}{l}0.547 \\
0.157 \\
0.253 \\
0.044 \\
\end{array}$ & \\
\hline Sex $[1=$ female] & 5,586 & 0.087 & \\
\hline Age & 5,586 & 47.56 & 7.579 \\
\hline
\end{tabular}


Figure 1: Relevance of bonus payments and tenure
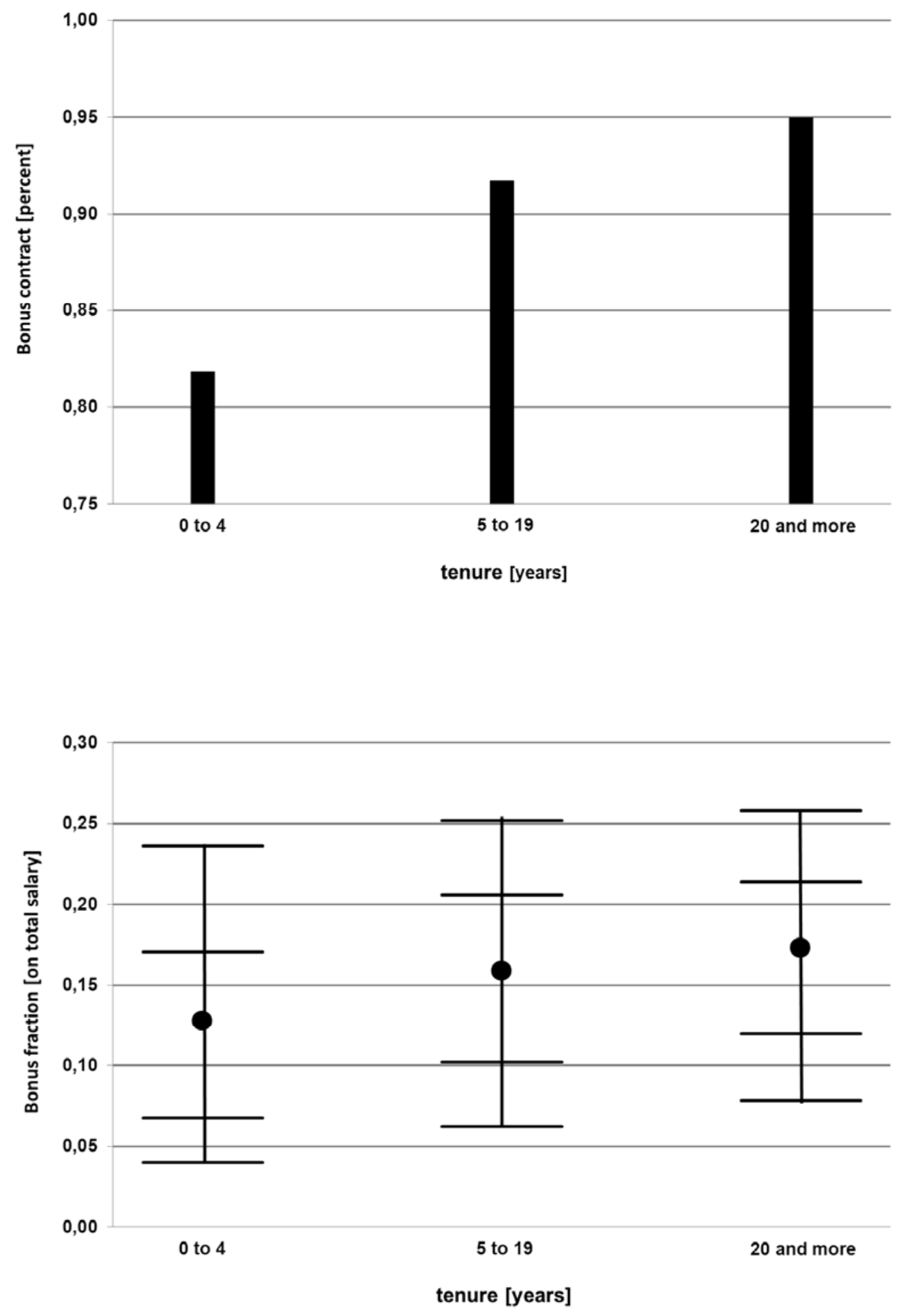

Notes: Figures show shares respectively means (dots) as well as percentiles (10th, 25th, 75th, 90th). 
Figure 2: Relevance of bonus payments and hierarchy levels
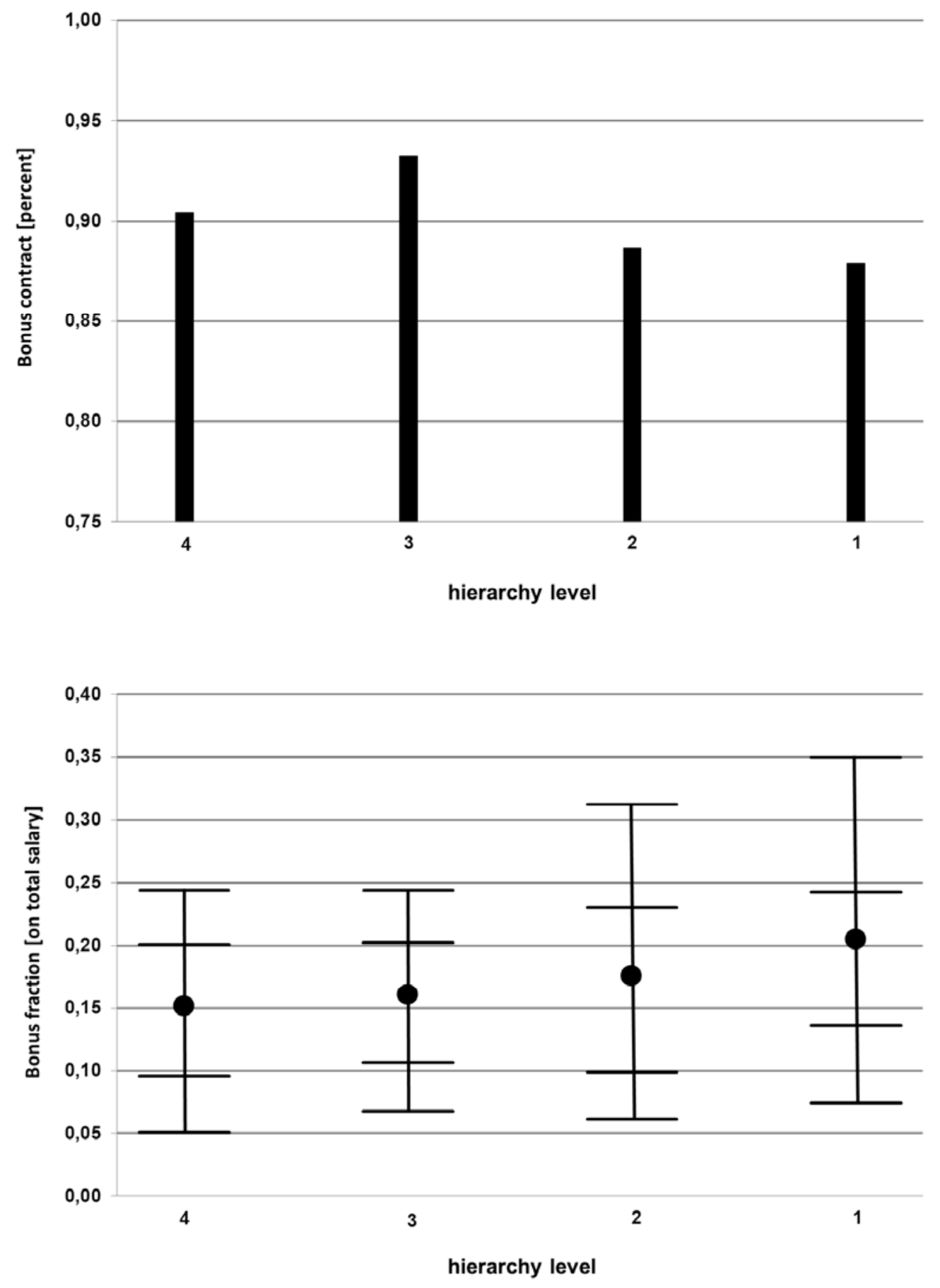

Notes: Figures show shares respectively means (dots) as well as percentiles (10th, 25th, 75th, 90th). 
Figure 3: Relevance of bonus payments and functional areas
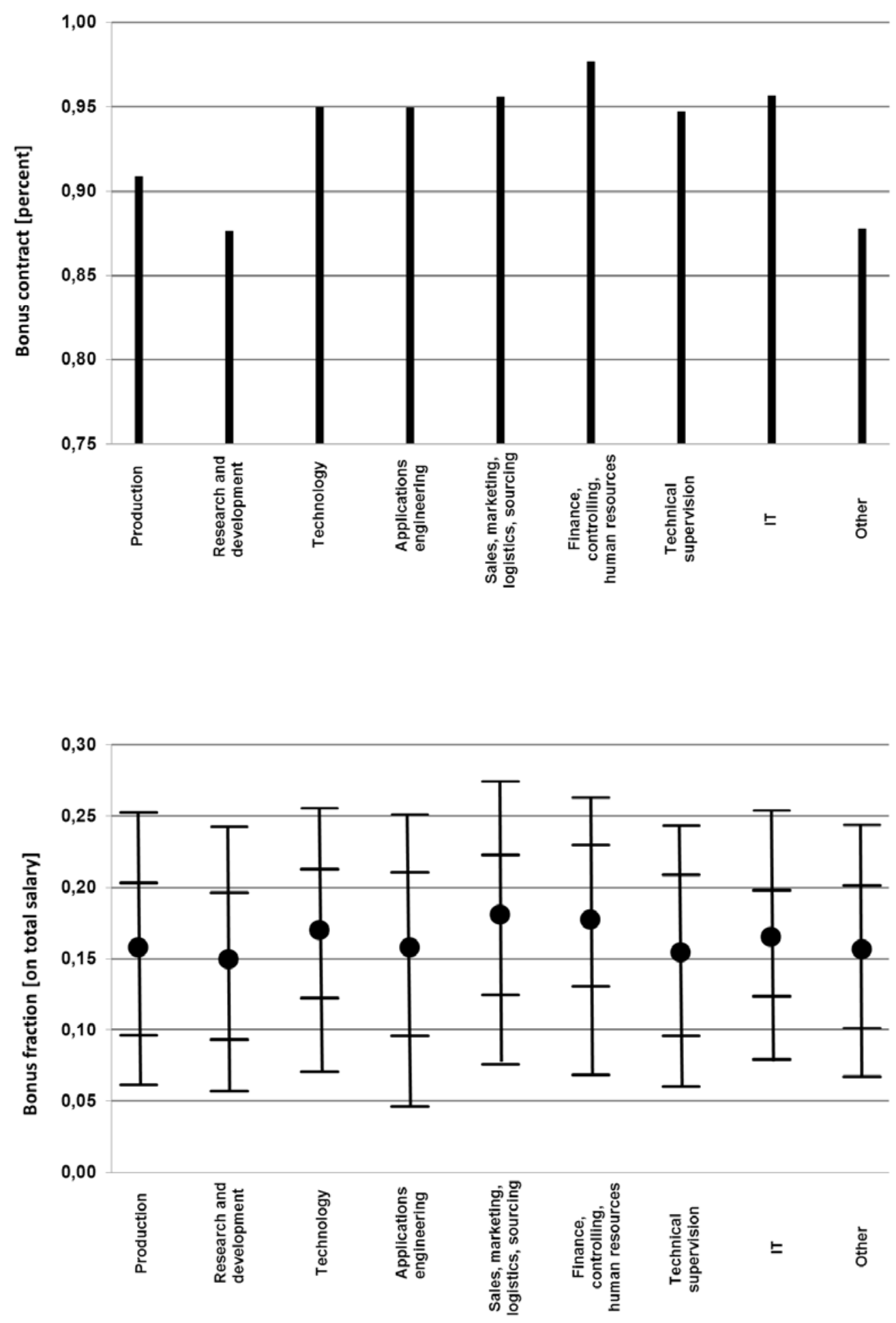

Notes: Figures show shares respectively means (dots) as well as percentiles (10th, 25th, 75th, 90th). 
Table 2 presents the results of our multivariate analysis. We run two regressions with our two bonus variables as dependent variables. Since the incidence of a bonus contract is a binary variable, we apply a binary probit approach here. An ordinary least square estimation is used for the regression on the fraction of the bonuses. In order to better interpret the coefficients, we stick to simple fractions. A transformation of the fraction $x$ by $\ln (x /(1-x))$ leads to the same results.

The results support our three hypotheses. Indeed, bonus payments are more relevant for employees with longer periods of tenure, for individuals with jobs at higher hierarchy levels, and for those with management rather than R\&D tasks. The results do not depend on the proxy for bonus relevance, but are robust for the incidence of bonus contracts and the fraction of bonus payments on total salary. All results are highly statistically significant.

In order to report the economic relevance, marginal effects for binary probit estimates can be calculated for the mean of other variables. Since bonus contracts are prevalent for most employees in the sector, marginal effects for bonus contracts are not too big. Additional ten years of tenure lead to an increase in the incidence of a bonus contract of 1.4 percentage points. Level 1 managers face a higher incidence in the amount of 3.4 percentage points than level 3 employees, and employees in management areas have a 4 percentage points higher incidence than R\&D workers. ${ }^{5}$ Differences with respect to the fraction of the bonus on total salary are more pronounced for level and job area than for tenure. The bonus fraction of level 1 managers is seven percentage points higher than at level 3. The fraction of employees at sales exceeds that of R\&D workers in the amount of three percentage points. ${ }^{6}$

\footnotetext{
${ }^{5}$ The detailed results with respect to marginal effects are provided by the authors on request.

${ }^{6}$ The results are also robust with respect to the absolute amount of bonus payments as a possible third indicator of bonus relevance. Differences concerning the amount of bonuses are somewhat pronounced. Interpreting the data as causal effects, each additional year of tenure increases the bonus in the amount of 1.4 percent. Executives at level 1 earn a bonus more than twice as high than the employees at level 3. Employees with management task receive considerably higher bonuses (sales, marketing, logistics: 33 percent, finance, controlling, hr: 20 percent) than R\&D workers.
} 
Table 2: Regressions on bonus relevance

\begin{tabular}{|c|c|c|}
\hline & $\begin{array}{l}\text { Bonus contract } \\
\text { (1=yes) } \\
\text { - Binary probit - }\end{array}$ & $\begin{array}{c}\text { Bonus fraction } \\
\text { - OLS - }\end{array}$ \\
\hline $\begin{array}{l}\text { Tenure [years] } \\
\text { Tenure squared }\end{array}$ & $\begin{array}{l}0.042 * * *(0.010) \\
-0.0009 * * *(0.0003)\end{array}$ & $\begin{array}{c}0.0030 * * *(0.0005) \\
-0.00006^{* * *}(0.00001)\end{array}$ \\
\hline $\begin{array}{l}\text { Level (base: level 3) } \\
1 \text { (top management level) } \\
4\end{array}$ & $\begin{array}{c}0.454 * * *(0.164) \\
0.174 * *(0.080) \\
-0.300^{* * *}(0.064)\end{array}$ & $\begin{array}{c}0.080 * * *(0.012) \\
0.031 * *(0.004) \\
-0.012 * * *(0.002)\end{array}$ \\
\hline $\begin{array}{l}\text { Job (base: research and development) } \\
\text { Production } \\
\text { Technology } \\
\text { Applications engineering } \\
\text { Sales, marketing, logistics, sourcing } \\
\text { Finance, controlling, human resources, } \\
\text { Technical supervision } \\
\text { IT } \\
\text { Other }\end{array}$ & $\begin{array}{ll}0.050 & (0.075) \\
0.205^{*} & (0.119) \\
0.444 * * * & (0.132) \\
0.577 * * * & (0.119) \\
0.644 * * * & (0.198) \\
0.354 * * * & (0.137) \\
0.262 & (0.237) \\
0.085 & (0.092) \\
\end{array}$ & $\begin{array}{lc}0.001 & (0.003) \\
0.008 * * & (0.004) \\
0.007 & (0.005) \\
0.028 * * * & (0.004) \\
0.016 * * * & (0.005) \\
0.001 & (0.004) \\
0.011 & (0.007) \\
0.006 * & (0.004) \\
\end{array}$ \\
\hline $\begin{array}{l}\quad \text { Firm size (base: } 1,001 \text { to } 2,000 \text { ) } \\
\text { Less than } 100 \text { employees } \\
101 \text { to } 300 \text { employees } \\
301 \text { to } 1,000 \text { employees } \\
\text { 2,001 to } 5,000 \text { employees } \\
\text { 5,001 to } 10,000 \text { employees } \\
\text { 10,001 to 30,000 employees } \\
\text { More than 30,000 employees }\end{array}$ & $\begin{array}{l}-1.137 * * *(0.118) \\
-0.775^{* * *}(0.113) \\
-0.534^{* * *}(0.098) \\
0.080 \quad(0.106) \\
0.418^{* * *}(0.122) \\
0.440^{* * *}(0.105) \\
0.594 * * *(0.118) \\
\end{array}$ & $\begin{array}{l}-0.040 * * *(0.009) \\
-0.033 * * *(0.007) \\
-0.019 * * *(0.005) \\
-0.009 * * \quad(0.005) \\
0.007 \quad(0.004) \\
0.019 * * *(0.004) \\
0.063 * * *(0.004) \\
\end{array}$ \\
\hline $\begin{array}{l}\text { Schooling (base: university degree) } \\
\text { University of applied sciences degree } \\
\text { Apprenticeship degree }\end{array}$ & $\begin{array}{rr}0.028 & (0.104) \\
-0.150 & (0.171) \\
\end{array}$ & $\begin{array}{l}-0.017 * * *(0.004) \\
-0.017 * *(0.007)\end{array}$ \\
\hline $\begin{array}{l}\quad \text { Field of study (base: chemistry) } \\
\text { Other natural sciences / medicine } \\
\text { Engineering } \\
\text { Business/economics }\end{array}$ & $\begin{array}{cc}-0.084 & (0.076) \\
0.036 & (0.082) \\
-0.150 & (0.181) \\
\end{array}$ & $\begin{array}{ll}0.004 & (0.003) \\
0.012^{* * *} & (0.003) \\
-0.001 & (0.006)\end{array}$ \\
\hline Sex $[1=$ female $]$ & $-0.234 * * *(0.086)$ & $-0,0064 * \quad(0.004)$ \\
\hline Age & $-0.001 \quad(0.005)$ & $0.0002 \quad(0.0002)$ \\
\hline Intercept & $1.156 * * *(0.229)$ & $0.103 * * *(0.010)$ \\
\hline Number of observations & 5,586 & 4,807 \\
\hline $\mathrm{R}^{2}$ & 0.184 & 0.216 \\
\hline
\end{tabular}

Notes: The table reports coefficients and robust standard errors. Significant result at the $10 \%, 5 \%$ and $1 \%$ level are indicated with $*, * *$ and $* * *$ respectively. 
To summarize, since tenure and job dummies as well as hierarchy levels are significantly associated to bonus relevance, the results are in line with our hypothetical considerations of section 2. In this sense, we can ascribe both the substitute and the complement argument empirical relevance. Although we cannot check strict causal effects, there are at least no empirical hints opposed to our considerations.

Our results are robust with respect to a number of different specifications. The hierarchy levels 1 to 4 might have a different meaning across firm size categories. Estimations for single categories generally lead to the same results, though. The tenure effects are somewhat more pronounced in large firms, whereas differences across functional areas are a little bit more relevant in smaller firms. Neither estimations for single hierarchy levels nor implementing interaction terms of hierarchy levels and tenure lead to additional than the general results.

It is worth mentioning that the two regressions of Table 2 are connected to each other. As stated above, most individuals have explicit bonus contracts and most of these indeed get a positive bonus. One may argue at first glance that some kind of double hurdle model might be relevant. However, there are also some managers, who state a positive bonus without having an explicit bonus contract. Nevertheless, managers receiving a bonus payment are not necessarily a random selection of all managers. In order to take into account a possible selection bias, a Heckman selection model (Heckman 1976) can be used, where the bonus fraction and the probability to get such a payment are estimated in one common approach (see Table $\mathrm{B}$ in the appendix). The results of the probit (selection) model coincide with the outcomes of the binary probit model of Table 2. The results with regard to determinants of the bonus fraction do not differ, either.

Firms may differ with respect to their bonus policy. As mentioned above, we can assign employees to certain firms in the majority of cases. It is therefore possible to analyze the bonus policy of single firms. We have more than 100 observations for four large corporations. We call these corporations ChemCorp A, B, C and D, respectively. In these four firms, almost all employees under considerations have bonus contracts. There are hardly any observations for level 1 employees so that we exclude the few observations and concentrate on the bonus fraction. Re-estimating the regression of Table 2 for employees of these four firms only lead to the same qualitative results compared to the general perspective of the chemical sector (see Table $\mathrm{C}$ in the appendix). However, the absolute level and relative importance of bonus payments differ considerably across firms. Employees of ChemCorp A receive much higher 
bonuses than employees of the other firms. We checked that bonus levels and fractions are positively correlated with some measures of firm performance such as growth of revenue. Firmwise estimations show that bonus payments are determined by tenure and level in most cases (see Table D in the appendix). Functional areas as supposed above are relevant only in two (A and D) of these firms, though.

In order to examine a particular relevance for recently hired employees, we re-estimate the specifications of Tables 2 described above with three categories of tenure instead of a metric tenure variable (see Table 3). Indeed, the results concerning tenure are mainly driven by employees with less than five years of tenure. This is true for the employees under consideration in general and also for three of the four large corporations of the chemical sector A, B and C. There are no meaningful differences between employees with 5 to 19 years of tenure and workers with at least 20 years at their firm. In contrast, bonuses are less relevant for recently hired employees with tenure up to 4 years, independent of the bonus dimension.

Table 3: Regression on bonus relevance - results for tenure categories (one regression per row)

\begin{tabular}{|c|c|c|c|}
\hline & & \multicolumn{2}{|c|}{ Tenure (base: 5 to 19 years) } \\
\hline & Dependent variable & $\begin{array}{c}0 \text { to } 4 \text { years of } \\
\text { tenure }\end{array}$ & $\begin{array}{c}20 \text { and more years } \\
\text { of tenure }\end{array}$ \\
\hline All observations & $\begin{array}{l}\text { Bonus contract } \\
\text { In Bonus } \\
\text { Bonus fraction }\end{array}$ & $\begin{array}{l}-0.203^{* * *}(0.072) \\
-0.255^{* * *}(0.039) \\
-0.021^{* * *}(0.004)\end{array}$ & $\begin{array}{ll}0.004 & (0.003) \\
0.070^{* *} & (0.028) \\
0.004 & (0.003)\end{array}$ \\
\hline ChemCorp A & $\begin{array}{l}\text { In Bonus } \\
\text { Bonus fraction }\end{array}$ & $\begin{array}{ll}-0.207 * * & (0.103) \\
-0.026 * & (0.015)\end{array}$ & $\begin{array}{lr}0.007 & (0.062) \\
0.0004 & (0.009)\end{array}$ \\
\hline ChemCorp B & $\begin{array}{l}\text { In Bonus } \\
\text { Bonus fraction }\end{array}$ & $\begin{array}{ll}-0.627 * & (0.353) \\
-0.045^{*} & (0.025)\end{array}$ & $\begin{array}{ll}0.122 & (0.083) \\
0.011 & (0.007)\end{array}$ \\
\hline ChemCorp C & $\begin{array}{l}\text { In Bonus } \\
\text { Bonus fraction }\end{array}$ & $\begin{array}{l}-0.681 * * *(0.252) \\
-0.048 * * \quad(0.020)\end{array}$ & $\begin{array}{ll}0.127 & (0.157) \\
0.003 & (0.181)\end{array}$ \\
\hline ChemCorp D & $\begin{array}{l}\text { In Bonus } \\
\text { Bonus fraction }\end{array}$ & $\begin{array}{ll}-0.097 & (0.159) \\
-0.007 & (0.014)\end{array}$ & $\begin{array}{ll}-0.154 & (0.108) \\
-0.009 & (0.009)\end{array}$ \\
\hline
\end{tabular}

Notes: Same specification as Table 2 and 3 (tenure dummies instead of tenure in years). The table reports coefficients and robust standard errors. Significant result at the $10 \%, 5 \%$ and $1 \%$ level are indicated with $*$, ** and $* * *$ respectively. 


\section{Conclusion}

We provide evidence for individual and job based characteristics that affect bonus payments for executives in Germany. Due to lack of data this issue has been addressed only insufficiently before. Our data set has the advantage that we are able to run firmwise regressions, which allow to examine possible differences in the bonus policies of single firms.

Using unique data from executive compensation in the German chemical industry we can show that bonus payments are in line with two different purposes within the long term wage policy of firms. First, bonuses substitute implicit career incentives when the ability of a manager is revealed over time. Second, bonuses also complement internal careers by generating strong job-promotion incentives via substantial employee rents at higher hierarchy levels. Our data contain information on tenure and hierarchy levels of executives next to detailed information on individual compensation so that the two effects can be disentangled.

Some limitations of our study occur due to data restrictions. Similar to Ortin-Angel and SalasFumas (1998), we only have a cross-section data set and cannot examine changes over a specific period of time. The possible problem of unobserved heterogeneity could be diminished with appropriate panel data. However, if the internal wage structures of the firms are rather stable over time, our cross-section analysis will give a reliable picture of the firms' bonus policies. For example, Baker, Gibbs and Holmström (1994a, 1994b) analyzed the wage policy of a single corporation over a period of 20 years and pointed out that both the organizational structure and the wage structure of the corporation do not significantly change during their observation period.

Both the substitutes approach and the complements approach are based on the assumption that there is sufficient internal mobility upwards the firms' hierarchies. Our cross-section data do not offer information on individual job promotion and executives' real opportunities of climbing up the corporate hierarchy. In addition, there may be certain positions that are regularly filled by hiring executives from outside. However, we know from discussions with VAA members and representatives that there is substantial internal promotion in the sector.

Analyzing the relation between bonus relevance and tenure, we have to state that the actual amount of the bonus usually depends on the performance of the individual (and also the performance of his division and the whole firm). If individual performance depends on tenure, 
it is even more difficult to identify causal effects. However, the incidence of a bonus contract variable is not hit by this problem and we show significant relevance for this variable, too.

Future work with repeated corresponding surveys may, for instance, contribute to the issues, to what extent bonuses and other wage components are affected by the recent economic crisis and whether this global crisis has long term effects in general or for certain cohorts of employees in particular.

\section{References}

Auriol, E., Friebel, G. and L. Pechlivanos (2002): Career Concerns in Teams, Journal of Labor Economics 20, 289-307.

Baker, G.P., Gibbs, M. and B. Holmström (1994a): The Internal Economics of the Firm: Evidence from Personnel Data, Quarterly Journal of Economics 109, 881-919.

Baker, G.P., Gibbs, M. and B. Holmström (1994b): The Wage Policy of a Firm, Quarterly Journal of Economics 109, 921-955.

Baker, G.P., Jensen, M.C. and K.J. Murphy (1988): Compensation and Incentives: Practice vs. Theory, Journal of Finance 43, 593-616.

Fama, E. (1980): Agency Problems and the Theory of the Firm, Journal of Political Economy 88, 288-307.

Gibbons, R. and K.J. Murphy (1992): Optimal Incentive Contracts in the Presence of Career Concerns: Theory and Evidence, Journal of Political Economy 100, 468-505.

Gibbs, M. (1995): Incentive Compensation in a Corporate Hierarchy, Journal of Accounting and Economics 19, 247-277.

Heckman, J. (1976): The Common Structure of Statistical Models of Truncation, Sample Selection, and Limited Dependent Variables and a Simple Estimator for Such Models, The Annals of Economic and Social Measurement 5, 475-492.

Holmström, B. (1982): Managerial Incentive Problems - A Dynamic Perspective, in Walross B. (ed.): Essays in Economics and Management in Honor of Lars Wahlbeck, Helsinki, 209-230.

Holmström, B. (1999): Managerial Incentive Problems: A Dynamic Perspective, Review of Economic Studies 66, 169-182.

Innes, R.D. (1990): Limited Liability and Incentive Contracting with Ex-ante Action Choices, Journal of Economic Theory 52, 45-67. 
Irlenbusch, B. and D. Sliwka (2006): Career Concerns in a Simple Experimental Labour Market, European Economic Review 50, 147-170.

Kim, S.K. (1997): Limited Liability and Bonus Contracts, Journal of Economics and Management Strategy 6, 899-913.

Koch, A.K., Morgenstern, A. and P. Raab (2009): Career Concerns Incentives: An Experimental Test, Journal of Economic Behavior and Organization 72, 571-588.

Kräkel, M. and A. Schöttner (2009): Internal Labor Markets and Worker Rents. Discussion Paper.

Kräkel, M. and A. Schöttner (2010): Minimum Wages and Excessive Effort Supply. Economics Letters 108, 341-344.

Lazear, E.P. (1995): Personnel Economics. Cambridge (Mass.)/London.

Lazear, E.P. (1998): Personnel Economics for Managers. New York et al.

Marino, A.M. and J. Zábojnik (2008a): Work-Related Perks, Agency Problems, and Optimal Incentive Contracts, RAND Journal of Economics 39, 565-585.

Marino, A.M. and J. Zábojnik (2008b): A Rent Extraction View of Employee Discounts and Benefits, Journal of Labor Economics 26, 485-518.

Murphy, K.J. (1999): Executive Compensation. In Ashenfelter, O. and D. Card (eds.): Handbook of Labor Economics, Volume 3b, 2485-2563.

Ockenfels, A., Sliwka, D. and P. Werner (2010): Bonus Payments and Reference Point Violations. IZA Discussion Paper No. 4795.

Ortin-Angel, P. and V. Salas-Fumas (1998): Agency-Theory and Internal-Labor-Market Explanations of Bonus Payments: Empirical Evidence from Spanish Firms, Journal of Economics and Management Strategy 7, 573-613.

Rosen, S. (1982): Authority, Control and the Distribution of Earnings, Bell Journal of Economics 13, 311-323.

Rosen, S. (1986): Prizes and Incentives in Elimination Tournaments, American Economic Review 76, 701-715.

Sappington, D. (1983): Limited Liability Contracts between Principal and Agent, Journal of Economic Theory 29, 1-21.

Smith, J.J. and T.T. Szabo (1977): The Dual Ladder - Importance of Flexibility, Job Content and Individual Temperament, Research Management 20, 20-23.

Treble, J., E. van Gameren; S. Bridges; T. Barmby (2001): The Internal Economics of the Firm: Further Evidence from Personnel Data, Labour Economics 8, 531-552. 


\section{Appendix}

Table A: Largest firms of the German chemical sector (ranked by 2008 revenue)

\begin{tabular}{|c|c|c|}
\hline Firm & $\begin{array}{l}\text { Revenue } \\
\text { (Mill. } € \text { ) }\end{array}$ & $\begin{array}{l}\text { Number of } \\
\text { employees }\end{array}$ \\
\hline BASF S.E. & 62,304 & 96,924 \\
\hline Bayer AG & 32,918 & 108,600 \\
\hline Evonik Industries AG & 15,873 & 40,767 \\
\hline Henkel KGaA & 14,131 & 55,513 \\
\hline Linde AG & 12,663 & 51,908 \\
\hline Fresenius S.E. & 12,336 & 122,217 \\
\hline Boehringer Ingelheim GmbH & 11,595 & 41,300 \\
\hline Merck KGaA & 7,558 & 32,800 \\
\hline Lanxess AG & 6,576 & 14,797 \\
\hline Beiersdorf AG & 5,971 & 21,766 \\
\hline $\mathrm{K}+\mathrm{S}$ AG & 4,797 & 12,368 \\
\hline Wacker Chemie AG & 4,298 & 15,922 \\
\hline B. Braun Melsungen AG & 3,786 & 37,601 \\
\hline Cognis GmbH & 3,001 & 5,900 \\
\hline Ratiopharm GmbH & 1,900 & n.a. \\
\hline Stada Arzneimittel AG & 1,646 & 8,318 \\
\hline SGL Carbon S.E. & 1,612 & 6,500 \\
\hline Westfalen AG & 1,500 & 1,205 \\
\hline Fuchs Petrolub AG & 1,394 & 3,855 \\
\hline Altana AG & 1,342 & 4,791 \\
\hline \multicolumn{3}{|l|}{ Subsidiaries of foreign firms } \\
\hline Sandoz International GmbH & 7,600 & 23,000 \\
\hline Dow Gruppe Deutschland & 4,835 & 6,532 \\
\hline Procter \& Gamble Deutschland GmbH & 4,650 & n.a. \\
\hline Basell Polyolefine GmbH & 4,646 & 2,585 \\
\hline Roche Deutschland Holding GmbH & 4,289 & 13,000 \\
\hline Sanofi-Aventis Deutschland GmbH & 4,000 & 10,000 \\
\hline Novartis Deutschland GmbH & 2,950 & 8,300 \\
\hline Unilever Deutschland GmbH & 2,414 & 1,961 \\
\hline Celanese GmbH & 2,100 & 2,850 \\
\hline Air Liquide Deutschland GmbH & 2,000 & 4,000 \\
\hline
\end{tabular}

Source: VCI 2009 (http://www.vci.de/default $\sim$ cmd shd docnr 94490 lastDokNr $\sim$-1.htm) 
Table B: Regressions on bonus relevance (Heckman selection model)

\begin{tabular}{|c|c|c|}
\hline & Prob (Positive Bonus) & Bonus fraction \\
\hline $\begin{array}{l}\text { Tenure [years] } \\
\text { Tenure squared }\end{array}$ & $\begin{array}{c}0.072 * * *(0.009) \\
-0.002 * * *(0.0003)\end{array}$ & $\begin{array}{l}0.0040 * * *(0.0008) \\
-0.00008 * * *(0.00002)\end{array}$ \\
\hline $\begin{array}{l}\text { Level (base: level 3) } \\
1 \text { (top management level) } \\
2 \\
4\end{array}$ & $\begin{array}{ll}0.288^{* * *} & (0.142) \\
0.093 & (0.070) \\
-0.256^{* * *} & (0.054)\end{array}$ & $\begin{array}{r}0.085^{* * *}(0.008) \\
0.033^{* * *}(0.003) \\
-0.015^{* * *}(0.003)\end{array}$ \\
\hline $\begin{array}{l}\text { Job (base: research and development) } \\
\text { Production } \\
\text { Technology } \\
\text { Applications engineering } \\
\text { Sales, marketing, logistics, sourcing } \\
\text { Finance, controlling, human resources, } \\
\text { Technical supervision } \\
\text { IT } \\
\text { Other }\end{array}$ & $\begin{array}{l}0.147^{* *}(0.067) \\
0.289^{* * *}(0.101) \\
0.446^{* * *}(0.110) \\
0.494^{* * *}(0.908) \\
0.500^{* * *}(0.143) \\
0.268^{* *}(0.112) \\
0.266 \quad(0.178) \\
0.084 \quad(0.078)\end{array}$ & $\begin{array}{lr}0.003 & (0.004) \\
0.013^{* * *}(0.005) \\
0.012^{* *} \quad(0.006) \\
0.033^{* * *}(0.005) \\
0.021^{* * *}(0.006) \\
0.004 & (0.005) \\
0.014 * & (0.008) \\
0.006 & (0.004)\end{array}$ \\
\hline $\begin{array}{l}\quad \text { Firm size (base: } 1,001 \text { to } 2,000 \text { ) } \\
\text { Less than } 100 \text { employees } \\
101 \text { to } 300 \text { employees } \\
301 \text { to } 1,000 \text { employees } \\
\text { 2,001 to 5,000 employees } \\
\text { 5,001 to } 10,000 \text { employees } \\
\text { 10,001 to } 30,000 \text { employees } \\
\text { More than } 30,000 \text { employees }\end{array}$ & $\begin{array}{l}-0.925 * * *(0.106) \\
-0.718^{* * *}(0.100) \\
-0.391 * * *(0.085) \\
0.256 * * *(0.938) \\
0.423 * * *(0.100) \\
0.429 * * *(0.087) \\
0.432 * * *(0.090)\end{array}$ & $\begin{array}{l}-0.056 * * *(0,013) \\
-0.044 * * *(0.010) \\
-0.240 * * *(0.006) \\
-0.006 \quad(0.005) \\
-0.004 \quad(0.005) \\
0.024 * * *(0.005) \\
0.067 * * *(0.005)\end{array}$ \\
\hline $\begin{array}{l}\text { Schooling (base: } \text { university degree) } \\
\text { University of applied sciences degree } \\
\text { Apprenticeship degree }\end{array}$ & $\begin{array}{ll}-0.069 & (0.088) \\
-0.328 * * & (0.147)\end{array}$ & $\begin{array}{l}-0.018 * * *(0.004) \\
-0.210 * * *(0.008)\end{array}$ \\
\hline $\begin{array}{l}\text { Field of study (base: chemistry) } \\
\text { Other natural sciences / medicine } \\
\text { Engineering } \\
\text { Business/economics }\end{array}$ & $\begin{array}{rr}-0.037 & (0.640) \\
0.041 & (0.068) \\
0.307 & (0.149)\end{array}$ & $\begin{array}{ll}0.003 & (0.003) \\
0.012 * * * & (0.003) \\
-0.001 & (0.006)\end{array}$ \\
\hline Sex $[1=$ female $]$ & $(0.076)$ & $--^{\mathrm{a}}$ \\
\hline Age & $-0.004 \quad(0.004)$ & $--^{\mathrm{a}}$ \\
\hline Intercept & $0.652 * * *(0.186)$ & $0.092^{* * *}(0.013)$ \\
\hline Number of observations & 5,586 & 4,807 \\
\hline$\lambda$ & 0.036 & $0.026)$ \\
\hline
\end{tabular}

Notes: The table reports coefficients and standard errors. Significant result at the $10 \%, 5 \%$ and $1 \%$ level are indicated with $*{ }^{* *}$ and ${ }^{* * *}$ respectively. ${ }^{a}$ sex and age have been skipped due to the necessity of having more independent variables in the selection model. 
Table C: Regressions on bonus relevance in four large corporations

\begin{tabular}{|c|c|}
\hline & $\begin{array}{c}\text { Bonus fraction } \\
\text { - OLS - } \\
\end{array}$ \\
\hline $\begin{array}{l}\text { Tenure [years] } \\
\text { Tenure squared }\end{array}$ & $\begin{array}{ll}0.0025^{* *} & (0.0012) \\
-0.00005^{*} & (0.00003) \\
\end{array}$ \\
\hline $\begin{array}{ll} & \text { Level (base: level 3) } \\
1 & \\
2 & \\
4 & \end{array}$ & $\begin{array}{r}\text { excluded } \\
0.059 * * *(0.012) \\
-0.019 * * *(0.004) \\
\end{array}$ \\
\hline $\begin{array}{l}\text { Job (base: research and development) } \\
\text { Production } \\
\text { Technology } \\
\text { Applications engineering } \\
\text { Sales, marketing, logistics, sourcing } \\
\text { Finance, controlling, human resources, } \\
\text { Technical supervision } \\
\text { IT } \\
\text { Other }\end{array}$ & $\begin{array}{ll}-0.002 & (0.006) \\
0.013 & (0.008) \\
0.002 & (0.007) \\
0.026^{* * *} & (0.009) \\
0.018^{* *} & (0.008) \\
0.002 & (0.008) \\
0.011 & (0.009) \\
0.008 & (0.008) \\
\end{array}$ \\
\hline $\begin{array}{l}\text { Schooling (base: university degree) } \\
\text { University of applied sciences degree } \\
\text { Apprenticeship degree }\end{array}$ & $\begin{array}{ll}-0.017 * * & (0.007) \\
-0.014 & (0.015)\end{array}$ \\
\hline $\begin{array}{l}\quad \text { Field of study (base: chemistry) } \\
\text { Other natural sciences / medicine } \\
\text { Engineering } \\
\text { Business/economics }\end{array}$ & $\begin{array}{cc}0.0007 & (0.007) \\
0.004 & (0.005) \\
-0.008 & (0.012) \\
\end{array}$ \\
\hline Sex [1=female] & $(0.008)$ \\
\hline Age & $(0.0006)$ \\
\hline $\begin{array}{l}\text { Firm dummies (base: ChemCorp A) } \\
\text { ChemCorp B } \\
\text { ChemCorp C } \\
\text { ChemCorp D }\end{array}$ & $\begin{array}{l}-0.053 * * *(0.005) \\
-0.092 * * *(0.007) \\
-0.111 * * *(0.005)\end{array}$ \\
\hline Intercept & $0.217 * * *(0.022)$ \\
\hline Number of observations & 743 \\
\hline $\mathrm{R}^{2}$ & 0.456 \\
\hline
\end{tabular}

Notes: The table reports coefficients and robust standard errors. Significant result at the $10 \%, 5 \%$ and $1 \%$ level are indicated with $*$, ** and $* * *$ respectively. 
Table D: Bonus relevance in four large corporations of the chemical industry

\begin{tabular}{|c|c|c|c|c|}
\hline & ChemCorp A & ChemCorp B & ChemCorp C & ChemCorp D \\
\hline & Bonus fraction & Bonus fraction & Bonus fraction & Bonus fraction \\
\hline Tenure [years] & $0.0035 * \quad(0.0019)$ & $0.0021 * *(0.0010)$ & $0.0044 \quad(0.0032)$ & $0.0009 \quad(0.0014)$ \\
\hline Tenure squered & $-0.00008(0.00005)$ & $-0.00002(0.00004)$ & $-0.00008(0.00009)$ & $-0.00007(0.00005)$ \\
\hline $\begin{array}{l}\text { Level (base: level 3) } \\
1 \text { (top management level) } \\
4 \\
4\end{array}$ & $\begin{array}{c}\text { excluded } \\
0.060 * * \quad(0.023) \\
-0.020 * * *(0.007) \\
\end{array}$ & $\begin{array}{ll}\text { excluded } & \\
0.0001 & (0.019) \\
-0.036^{* * *}(0.007) \\
\end{array}$ & $\begin{array}{ll}\text { excluded } & \\
0.127 * * * & (0.023) \\
0.016 \quad(0.018) \\
\end{array}$ & $\begin{array}{ll}\text { excluded } & \\
0.037 * * * \quad(0.012) \\
-0.037 * * *(0.006)\end{array}$ \\
\hline $\begin{array}{l}\quad \text { Job (base: } r \& d) \\
\text { Production } \\
\text { Technology } \\
\text { Applications engineering } \\
\text { Sales, marketing, logistics, ... } \\
\text { Finance, controlling, hr } \\
\text { Technical supervision } \\
\text { IT } \\
\text { Other }\end{array}$ & $\begin{array}{cc}0.007 & (0.010) \\
-0.001 & (0.001) \\
-0.002 & (0.009) \\
0.017 & (0.015) \\
0.015 & (0.012) \\
-0.003 & (0.011) \\
0.040 * * & (0.020) \\
-0.002 & (0.010) \\
\end{array}$ & $\begin{array}{ll}-0.006 & (0.016) \\
0.001 & (0.014) \\
0.016 & (0.014) \\
0.004 & (0.013) \\
0.025^{*} & (0.014) \\
-0.002 & (0.013) \\
-0.005 & (0.013) \\
0.003 & (0.014) \\
\end{array}$ & $\begin{array}{ll}-0.035 * * & (0.018) \\
-0.005 & (0.023) \\
0.005 & (0.018) \\
0.022 & (0.025) \\
0.005 & (0.026) \\
0.007 & (0.028) \\
0.013 & (0.022) \\
0.037 & (0.027) \\
\end{array}$ & $\begin{array}{ll}0.012 * & (0.007) \\
0.049 * * * & (0.016) \\
& \\
0.094^{* * *} & (0.020) \\
0.056^{* * *} & (0.006) \\
0.021^{* *} & (0.009) \\
-0.009 & (0.023) \\
0.001 & (0.009) \\
\end{array}$ \\
\hline $\begin{array}{l}\text { Schooling (base: university) } \\
\text { University of applied sciences degree } \\
\text { Apprenticeship degree }\end{array}$ & $\begin{array}{ll}-0.019 & (0.011) \\
-0.043 & (0.031)\end{array}$ & $\begin{array}{lc}-0.018 & (0.012) \\
-0.055^{* * *} & (0.017)\end{array}$ & $\begin{array}{ll}-0.002 & (0.018) \\
-0.092 * * * & (0.034)\end{array}$ & $\begin{array}{rr}-0.020 & (0.013) \\
0.015 & (0.017)\end{array}$ \\
\hline $\begin{array}{l}\text { Field of study (base: chemistry) } \\
\text { Other sciences / medicine } \\
\text { Engineering } \\
\text { Business/economics }\end{array}$ & $\begin{array}{l}(0.012) \\
(0.007) \\
(0.021)\end{array}$ & $\begin{array}{ll}0.021 & (0.036) \\
-0.011 & (0.009) \\
-0.014 & (0.015) \\
\end{array}$ & $\begin{array}{l}(0.019) \\
(0.017) \\
(0.030) \\
\end{array}$ & $\begin{array}{ll}-0.008 & (0.007) \\
-0.009 & (0.008) \\
-0.051^{* *} & (0.019) \\
\end{array}$ \\
\hline Sex [1=female] & $(0.014)$ & $-0.031^{* *}$ & $(0.020)$ & $-0,007 \quad(0.009)$ \\
\hline Age & $-0.001 \quad(0.001)$ & $\begin{array}{ll}-0.001 \quad(0.001) \\
\end{array}$ & $(0.002)$ & $0.0019 * * *(0.0007)$ \\
\hline Intercept & $0.254 * * *(0.032)$ & $0.239 * * *(0.036)$ & $(0.069)$ & $0.055^{*} \quad(0.030)$ \\
\hline Number of observations & 317 & 178 & 136 & 112 \\
\hline $\mathrm{R}^{2}$ & 0.166 & 0.237 & 0.458 & 0.634 \\
\hline
\end{tabular}

Notes: The table reports coefficients and robust standard errors. Significant result at the $10 \%, 5 \%$ and $1 \%$ level are indicated with *, ** and *** respectively. 